\title{
Mr. Sead BANDŽOVIĆ
}

Pravni fakultet Univerziteta u Sarajevu

E-mail: sead1994@live.com

Pregledni rad/Review article

UDK/UDC:94:34:342.4(497:497.6)“1921“"

$34: 342.4(497: 497.6)$ “1921“"

\section{„TURSKI PARAGRAF“ VIDOVDANSKOG USTAVA (1921): DOMETI I OGRANIČENJA}

Apstrakt: Jedna od krupnih posljedica Prvog svjetskog rata je, pored ogromnih materijalnih razaranja i ljudskih žrtava, nestanak nekih velikih carstava (Ruskog, Njemačkog, Habsburškog i Osmanskog) sa historijske i političke karte Evrope i svijeta. Na njihovim ruševinama su, u različitim okolnostima, stvarane nove države pa je tako, uz uticaj međunarodnog faktora, u decembru 1918. ujedinjenjem Države Hrvata, Srba i Slovenaca i Kraljevine Srbije stvorena Kraljevina Srba, Hrvata i Slovenaca (Kraljevina SHS), kasnije preimenovana u Kraljevinu Jugoslaviju (1929). U njenom sastavu se našla i Bosna i Hercegovina čiji se subjektivitet $u$ novoj državi mijenjao u nekoliko faza. To je predstavljalo rezultat političkih procesa, unutrašnjih sukoba srpskih, hrvatskih i drugih političkih snaga. U ovom radu pozornost je usmjerena na Vidovdanski ustav, na postupak njegovog donošenja sa posebnim osvrtom na njegov član 135. ("turski paragraf") koji je, između ostaloga, nekoliko godina očuvao teritorijalni integritet Bosne $i$ Hercegovine unutar države. "Turski paragraf" je prestao da važi 1924, kada se, shodno drugim odredbama Vidovdanskog ustava, završava organizovanje oblasti u državi i zavodi centralizacija uprave.

Ključne riječi: Kraljevina SHS/Jugoslavija, državna organizacija, Vidovdanski ustav (1921), "turski paragarf”, Bosna i Hercegovina.

\section{„TURKISH PARAGRAPH“ OF THE VIDOVDAN CONSTITUTION (1921): SCOPE AND LIMITATIONS}

\begin{abstract}
Among the major consenquences of the World War I, besides huge destructions and human casualties, disappearance of old empires (Ottoman, Austro-Hungarian, Rusian and German) and emerge of new states in Europe under international influence can be mentioned. In December 1918 State of Croats, Serbs and Slovenians had united with Kingdom of Serbia and formed Kingdom of Serbs, Croats and Slovenians (later renamed in Kingdom of Yugoslavia in 1929). Bosnia
\end{abstract}


and Herzegovina, as a part of this Kingdom, changed its political subjectivity in few phases which was a result of political processes and internal conflicts of Serbian, Croatian and other politicians. In this paper the focus is put on the Vidovdan Constitution, its promulgation with special review of Article Nr. 135 of this Constitution also known as Turkish Article. This Article managed to preserve teritorial integrity of Bosnia and Herzegovina in Kingdom of Serbs, Croats and Slovenians until 1924. when, according to the other provisions of the Constitution, the process of govermnent establishing had finished and the new centralised governing sistem came into power.

Key words: Kingdom of Serbs, Croats, Slovenians / Yugoslavia, Vidovdan Constitution (1921), Turkish Article, Bosnia and Herzegovina.

Prvodecembarskim aktom 1918. osnovano je Kraljevstvo Srba, Hrvata i Slovenaca. Radilo se o činu ujedinjenja Kraljevine Srbije sa Državom Slovenaca, Hrvata i Srba. ${ }^{1}$ Bio je to kompromis tadašnjeg Narodnog vijeća Slovenaca, Hrvata $i$ Srba koje je, zbog teških ekonomskih i političkih prilika i mogućnosti da italijanska vojska zauzme znatna slovenska i hrvatska područja, odustalo od prvobitnog federalnog uređenja buduće države proklamovanog u ,Naputku“ Narodnog vijeća od 24. novembra 1918. i umjesto toga je adresom pozvalo srpskog regenta Aleksandra I Karađorđevića da preuzme vlast u cijeloj državi. Regent je odgovorio proklamacijom kojom je, u ime svog oca Petra I Karađorđevića, proglasio ujedinjenje Kraljevine Srbije sa Državom Slovenaca, Hrvata i Srba u jedinstveno Kraljevstvo Srba, Hrvata i Slovenaca. ${ }^{2}$ U Prvodecembarskom aktu nisu se našli zahtjevi Narodnog vijeća da se državno uređenje riješi na sveopštoj skupštini Srba, Hrvata i Slovenaca kvalifikovanom dvotrećinskom većinom. Predviđena je uspostava privremenog državnog uređenja sve do donošenja novog ustava. Ubrzo, nakon Prvodecembarskog akta, kojim je proglašeno ujedinjenje, formirano je 12 . marta 1919. Privremeno narodno predstavništvo, kojem je bio centralni zadatak da

1 Potpisivanjem mirovnog ugovora s Njemačkom 28. juna 1919. godine Kraljevstvo Srba, Hrvata i Slovenaca postalo je međunarodno priznata država. Kraljevstvo je 1921. promijenilo ime u Kraljevina Srba, Hrvata i Slovenaca.

2 Srpski su političari, kako oni iz Srbije, tako i oni iz Bosne i Hercegovine, zapaža Ivan Markešić, u novu državu ušli svjesni ciljeva koje su trebali u njoj postići. Činom stvaranja Kraljevine Srba, Hrvata i Slovenaca, ostvarit će se njihove težnje za uspostavom države u kojoj će svi Srbi živjeti zajedno. Temeljem vojnih uspjeha srpske vojske na kraju Prvog svjetskog rata "oni su polagali pravo na primat u odlučivanju u novostvorenoj državi. Kako je među hrvatskim političkim i crkvenim elitama vladalo dijametralno suprotno stajalište u odnosu na novu državu, srpskim političarima nije bilo teško postaviti temelje vlastitoga i presudnoga utjecaja. Oni su sav svoj oficirski kadar unijeli u novu državu. Hrvati i Muslimani ga nisu ni imali. Ako je i postojao, hrvatski su se i muslimanski časnici borili na strani gubitnika u tom ratu, na strani Austro-Ugarske. Srbi su u novu državu unijeli i sav diplomatski zbor, državnu administraciju te pravoslavlje kao državnu religiju" - prema: Ivan Markešić, Vjerske i crkvene prilike u Bosni i Hercegovini nakon I. svjetskog rata, u: Fra Didak Buntić - čovjek $i$ djelo, uredili Stipe Tadić i Marinko Šakota, Institut društvenih znanosti Ivo Pilar, Zagreb 2009, 107. 
pripremi izbore za ustavotvornu skupštinu i da organizuje početak njenog rada. ${ }^{3}$ Tako je vlast u cijeloj zemlji bila skoncentrisana u rukama Privremenog narodnog predstavništva, vlade i regenta Aleksandra I Karađorđevića. ${ }^{4}$ Rađanje nove države, sa nizom slutnji i nepoznanica, u cjelini je stvorilo više problema nego što ih je riješilo. ${ }^{5}$ Nacionalni problemi ugrađeni su u njeno biće i sudbinu. Različite političke strategije vezane uz partikularne nacionalne ideologije formirane su znatno puno prije nastanka jugoslavenske ideologije i stvaranja države 1918. godine. ${ }^{6} \mathrm{U}$ srži sporova koji su je potresali, od prvih dana njenog postojanja do njenog sloma 1941, bilo je pitanje državnog uređenja. Zagovornici unitarizma i velikosrpske verzije države suprotstavljali su se predstavnicima nesrpskih nacionalnih pokreta koji su tražili federativno (ili konfederalno) državno uređenje. ${ }^{7}$

Regent je 20. decembra 1918. imenovao prvu vladu sa predstavnicima iz svih dijelova nove države predvođenu radikalskim predstavnikom Stojanom Protićem. U sastav nove vlade ušla su i tri ministra iz Bosne i Hercegovine: Tugomir Alaupović za resor vjera, Uroš Krulj za narodno zdravlje i Mehmed Spaho za oblast šuma i ruda. Proces uspostave vlade pratile su određene nesuglasice i odstupanja od ranijih političkih dogovora. Tako je prema prvobitnoj ideji predsjednik nove vlade trebao biti Nikola Pašić, međutim on je upućen na Mirovnu konferenciju u Pariz. Slični problemi su pratili i uspostavu Privremenog narodnog predstavništva. Prvodecembarskim aktom je utvrđeno da ce se sastav predstavništva utvrditi naknadnim sporazumom između Srbije i Narodnog vijeća iz Zagreba. Međutim, ministar za Ustavotvornu skupštinu i izjednačenje zakona, dr. Albert Kramer donio je, po regentovom zahtjevu, spisak članova Predstavništva. U njegov sastav ušla su 32 poslanika iz Slovenije, iz Hrvatske sa Slavonijom, Rijekom i Međumurjem 62, Istre 4, Dalmacije 4, Vojvodine 24, Srbije 84, Crne Gore 12 i Bosne i Hercegovine 42 člana. Vlada je ograničavala Predstavništvo u korištenju svih njegovih ovlaštenja u punom kapacitetu. Od predloženih 47 zakona doneseno je samo njih 12 u godinu i po postojanja ove institucije. Sjednice Predstavništva su često praćene sukobima zbog samog načina odabira članova. ${ }^{8}$

3 Privremeno narodno predstavništvo je, zajedno sa Kraljem, donijelo 3. septembra 1919. Zakon o izboru narodnih poslanika za ustavotvornu skupštinu - vidi: Miroslav Đorđević, Istorijat izbora u Kraljevini SHS i Kraljevini Jugoslaviji, Strani pravni život, br. 3, Institut za uporedno pravo, Beograd 2013, 298.

4 Osman Sušić, Položaj Bosne i Hercegovine u Vidovdanskom ustavu - historijski okvir aktuelne ustavno pravne teme u: Edin Mutapčić (ur), Zbornik radova naučnog skupa: Ustavno pravni razvoj Bosne i Hercegovine (1910 - 2010), Pravni fakultet Univerziteta u Tuzli, Tuzla 2011, 227-237. (dalje: O. Sušić, Položaj Bosne i Hercegovine u Vidovdanskom ustavu).

5 Holm Zundhausen, Istorija Srbije od 19. do 21. veka, Clio, Beograd 2008, 261.

6 Opšir. Igor Ivašković, The Vidovdan Constitution and the Alternative Constitutional Strategies, Zbornik Pravnog fakulteta u Zagrebu, br. 3-4, Zagreb 2018, 525-551.

7 Ivo Banac, Nacionalno pitanje u Jugoslaviji: porijeklo, povijest, politika, Durieux, Zagreb 1995, 174.

8 Mustafa Imamović, Historija države i prava Bosne i Hercegovine, Magistrat, Sarajevo 2014, 285 286. (dalje: M. Imamović, Historija države i prava Bosne i Hercegovine). 
Unifikacija prava je bila jedan od prioritet nove vlasti. Već prilikom formiranja prve vlade Kraljevine SHS, ustanovljeno je Ministarstvo za izjednačavanje zakona. ${ }^{9}$ Položaj Bosne i Hercegovine u privremenom državnom uređenju bilo je određen ukidanjem Narodnog vijeća za Bosnu i Hercegovinu 31. decembra 1918. i reformom bosanskohercegovačke Narodne vlade. ${ }^{10}$ Vlada je u početku imala deset povjerenstava, ali su, u skladu sa tendencijama političke centralizacije, pojedini resori preneseni na centralni nivo u Beograd. Riječ je o vanjskim i vojnim poslovima, finansijama, obrtu i industriji, obnovi zemlje i trgovini. ${ }^{11}$ Narodna vlada, naknadno preimenovana u Zemaljsku, raspolagala je sa četiri odjela: unutrašnjim poslovima, pravosuđem, poljoprivredom, vjerskim i obrazovnim poslovima. Proces centralizacije tekao je poprilično sporo pa je Zemaljska vlada nastavila sa radom još nekoliko godina. Regent je 26. februara 1919. izdao naredbu o uspostavi funkcije delegata ministarstva finansija pri vladi u Bosni i Hercegovini. Njemu je, nakon određenog vremena, dodat i povjerenik za javne radove i željeznice. ${ }^{12}$

U skladu sa Zakonom o Ustavotvornoj skupštini Privremeno narodno predstavništvo je u cijeloj državi raspisalo i zakazalo izbore za 28. novembar 1920. godine. Na raspolaganju su bila ukupno 419 mandata, a u predizbornoj

9 Vidovdanski ustav (1921) je članom 133. predviđao kraći zakonodavni postupak prilikom donošenja zakona koji se tiču izjednačavanja prava - vidi: Amra Mahmutagić, Pravna heterogenost u zajedničkoj jugoslavenskoj državi između dva svjetska rata, Revija za pravo i ekonomiju, br. 1, Pravni fakultet, Univerzitet Džemal Bijedić u Mostaru, Mostar 2016, 12.

10 Ljubomir Zovko, Studije iz pravne povijesti Bosne i Hercegovine 1878-1941, Pravni fakultet Sveučilišta u Mostaru, Mostar 2007, 56-58. (dalje: Lj. Zovko, Studije iz pravne povijesti Bosne $i$ Hercegovine). Samo proglašenje Kraljevstva Srba, Hrvata i Slovenaca 1. decembra 1918, konstatira Husnija Kamberović, u širim narodnim masama u Bosni i Hercegovini nije praćeno velikim manifestacijama oduševljenja, "a ostaje i sporno koliko je ta vijest bila poznata običnim ljudima. Činjenica da su iz nekih krajeva Bosne i Hercegovine telegrami o izravnom ujedinjenju sa Srbijom upućivani u Beograd i poslije 1. decembra, dakle nakon proglašenja nove države, ostavlja dovoljno prostora za razne interpretacije ne samo o piscima tih telegrama nego i o stvarnom stanju na terenu nakon proglašenoga ujedinjenja. Obični ljudi su imali drugih problema: srpski seljaci su koristili vrijeme nestabilnosti i nedovoljno efikasne vlasti da maltretiraju zemljoposjednike i otimaju njihovu zemlju, muslimanski zemljoposjednici su tražili način da zaštite svoje živote, a obični ljudi su gledali kako da prežive hladnu i gladnu zimu". Pojedine zajednice u Bosni i hercegovini, iako formalno ravnopravne, nakon proglašenja ujedinjenja u novu državu suočavale su s različitim izazovima na terenu: "Muslimanski zemljoposjednici su pogođeni agrarnom reformom, muslimansko i hrvatsko stanovništvo je trpjelo pljačke i napade, posebno u pograničnim krajevima sa Crnom Gorom, a političke elite, koje su se organizirale u političke stranke na vjerskoj i nacionalnoj osnovi, osim Komunističke partije koja u prvi plan stavlja socijalna, a ne vjerska i nacionalna pitanja, bile su zaokupljene debatama o broju mjesta u privremenim zastupničkih institucijama, ne toliko zbog uvjerenja da je to pokazatelj stvarnog položaja Bosne i Hercegovine kao cjeline u Jugoslaviji, nego više zbog narativa da će na taj način najbolje braniti vjerske ili nacionalne interese zajednice u čije ime su nastupali" - prema: Husnija Kamberović, U stalnom procepu, u: Jugoslavija u istorijskoj perspektivi, Helsinški odbor za ljudska prava u Srbiji, Beograd 2017, 64. (dalje: H. Kamberović, $U$ stalnom procepu).

11 Lj. Zovko, Studije iz pravne povijesti Bosne i Hercegovine, 57-59.

12 M Imamović, Historija države i prava Bosne i Hercegovine, 286-287. 
kampanji su učestvovale 22 političke stranke. Glasalo se putem kuglica, budući da je velik procenat stanovništva bio nepismen. Izbornu pobjedu su odnijele tri stranke: Demokratska stranka sa 92 poslanička mjesta, Narodna radikalna sa 91, Komunistička partija Jugoslavije 58 i Hrvatska pučka republikanska stranka Stjepana Radića 50. Među deset najjačih stranaka u Ustavotvornoj skupštini bili su: Savez zemljoradnika, Samostalna kmetijska stranka (tzv. slovenački radikali dr. Bogumila Vošnjaka), Slovenska ljudska stranka (SLS), Jugoslovenska muslimanska organizacija (JMO), Hrvatska pučka i Bunjevačko-šokačka stranka, Socijaldemokratska stranka te Džemijet. U Bosni i Hercegovini poseban uspjeh je zabilježila (JMO) na čelu sa Mehmedom Spahom. ${ }^{13}$ Ova stranka je u Bosni i Hercegovini osvojila skoro sve raspoložive mandate čime je u Konstituanti dobila 24 mjesta. Razlozi za uspjeh JMO-a na izborima u Bosni i Hercegovini su u lošim ekonomskim prilikama muslimana i stranačkom programu koji je uspio na jednom mjestu okupiti sve muslimanske birače bez obzira na njihovu klasnu pripadnost $i$ socijalno porijeklo. Kako su ovi glasovi zajedno sa šest muslimanskih predstavnika iz Makedonije mogli ostvariti prevagu u skupštini brojni političari su nastojali pridobiti ove poslanike da djeluju u njihovu korist. Jedan od primarnih zadataka JMO bilo je ublažavanje posljedica agrarnih reformi. Nova vlada je 1919. ukinula kmetstvo i novim zakonom ustanovila pravo vlasništva bivših kmetovskih porodica nad zemljom koju obrađuju. Ta reforma je pogodila skoro 4.000 muslimanskih zemljoposjedničkih porodica, a Spahin cilj bilo je osigurati pravičnu naknadu za oduzete posjede. Odšteta je na kraju isplaćivana, ali to je bilo daleko ispod tržišne vrijednosti zemlje. Zbog ovakvog djelovanja kritičari su prebacivali JMO da djeluje u korist stare feudalne klase iako su na izbornim listama od 78 kandidata svega njih šest bili zemljoposjednici. Pored tretiranja agrarne problematike JMO se u svom političkom programu djelovanja zalagala za očuvanje regionalno-administrativnog identiteta Bosne i Hercegovine. ${ }^{14}$

Vlada je, po okončanju izbora, propisala privremeni poslovnik za Konstituantu kojim je određeno da niti jedan poslanik ne može preuzeti mandat dok prethodno ne položi zakletvu kralju. Time se umnogome prejudiciralo rješenje dvojbe - republika ili monarhija. ${ }^{15}$ Indirektno je data značajna uloga kralju kao političkom akteru u novoj državi i simbolu monarhijskog uređenja, a o čijoj su se prirodi poslanici tek trebali dogovoriti kroz predstojeće rasprave o budućem ustavnom sistemu države. Osnovna obaveza Ustavotvorne skupštine bila je donošenje ustava, a s obzirom na raznovrsnost političkih snaga pojavile su se dvije struje unutar skupštine. Jedna je težila ka strogom centralističkom, unitarnom uređenju države dok su sa druge strane postojale opozicione snage koje su težile ka autonomnim i federalističkim rješenjima. Postojala je tvrda opozicija (Radićeva HSS, crnogorski „zelenaši“ - pristalice autonomije Crne Gore, Hrvatska

\section{Isto, 291.}

14 Noel Malcom, Povijest Bosne, Erasmus Gilda, Zagreb 1995, 222-223.

15 Ivo Goldstein, Suprotstavljanje centralizmu, u: Jugoslavija u istorijskoj perspektivi, Helsinški odbor za ljudska prava u Srbiji, Beograd 2017, 121. (dalje: I. Goldstein, Suprotstavljanje centralizmu). 
stranka prava - frankovci, albanski „kačaci“, komunisti i Unutrašnja makedonska revolucionarna organizacija). Nešto umjereniju, autonomističku struju činili su Jugoslovenska muslimanska organizacija, Džemijet, Slovenska ljudska stranka i liberalni hrvatski intelektualci.

U raspravama o oblicima državnog uređenja, Bosna i Hercegovina i Vojvodina zauzimale su posebno mjesto. ${ }^{16}$ Krajem januara 1921. unutar skupštine je formiran poseban Ustavni odbor koji je prikupljao i analizirao pristigle nacrte ustava. Podneseno je više različitih nacrta ustava, od kojih je centralno mjesto zauzimao nacrt vlade Nikole Pašića, koji je "služio kao osnov za načelnu diskusiju". ${ }^{17}$ Svi nacrti su se mogli svrstati u tri grupe. U prvoj su zastupana federalistička uređenja sa manjim ili većim stepenom decentralizacije. U drugoj skupini je propagirano umjereno centralističko, dok se u trećoj išlo ka striktno centralističkom državnom uređenju. ${ }^{18}$ Od svih pristiglih nacrta najvišu podršku je uživao vladin prijedlog koji je, zahvaljujući odredbama privremenog Poslovnika Ustavotvorne skupštine, te same podrške vladajućih državnih političkih krugova, imao najviše izgleda za usvajanje. Ovaj draft je izrađen po uzoru na srpski ustav iz 1888. i 1903. godine, kao i ideja Prvodecembarskog akta i Krfske deklaracije. Predloženim ustavom je predviđeno da se ozakoni centralistički uređena monarhija sa ograničenim pravima parlamenta i vrlo širokim ovlaštenjima kralja. ${ }^{19} \mathrm{Ka}$ ovakvom uređenju stremili su najviše srpski političari u Konstituanti na bazi zajedničkog djelovanja radikala i demokrata. Centralističko uređenje i monarhija smatrali su se idealom i željenim ciljom tadašnjih političkih elita u Srbiji. ${ }^{20}$ Isključivana je bilo kakva mogućnost podjele Kraljevine na historijske pokrajine, a Nikola Pašić je prilikom osnivanja Konstituante tvrdio da nema mjesta ikakvom kakvom obliku majorizacije budući da su Srbi, Hrvati, Slovenci, kao troplemeni narod, tretirani kao jedinstvena cjelina. ${ }^{21}$ Tokom rasprave o ovom nacrtu Skupštinu

16 Mira Radojević, Srpsko-hrvatski spor oko Bosne i Hercegovine i Vojvodine u periodu Kraljevine Srba, Hrvata i Slovenaca, Dijalog povjesničara-istoričara, knj. 2, Zagreb 2000, 327-328.

17 Miroslav Đorđević, Istorijat izbora u Kraljevini SHS i Kraljevini Jugoslaviji, Strani pravni život. br. 3, Institut za uporedno pravo, Beograd, Univerzitet u Beogradu, Pravni fakultet, Beograd 2013, 299. (dalje: M. Đorđević, Istorijat izbora u Kraljevini SHS i Kraljevini Jugoslaviji).

18 M. Imamović, Historija države i prava Bosne i Hercegovine, 292.

19 Isto, 292.

20 Ambicija vladajuće radikalsko-demokratske koalicije bila je, u žustrim raspravama o ustavu u Ustavotvornoj skupštini, da nametne rješenja u svim pitanjima državnog ustrojstva i političkog života zemlje. Odbijani su svi nacrti, prijedlozi i primjedbe ne samo opozicionih stranaka, već i umjerenijih političara iz vladajućih krugova (na primjer, Stojana Protića). Mate Drinković, tada član Privremenog narodnog predstavništva, te od 1920. ministar pošta, upozorio je predlagače centralističke opcije: "Gospodo, vi svi vrlo dobro znate kuda vodi ovakav ustav", pa nastavio: "Takav centralizam je veoma pogibeljan za našu državu, jer uslijed samovolje njegove mora silom prirodnih zakona da se razvije protiv nje organizovan otpor, koji može dovesti do veoma ozbiljne pogibelji” - prema: I. Goldstein, Suprotstavljanje centralizmu, 121.

21 Opšir. Safet Bandžović, Spone i sporovi: Bosna i Hercegovina u jugoslavenskoj državi (1918 - 1941) u: Adisa Pašalić Kreso, Mirko Pejanović, Vera Katz (ur), Zbornik radova: Međunarodna naučna konferencija: 75. godišnjica Prvog zasjedanja ZAVNOBIH-a: Povijesna utemeljenost obnovljene državnosti Bosne i Hercegovine u 20. i 21. stoljeću, Akademija nauka i umjetnosti Bosne i 
su napustili predstavnici Narodnog kluba (Hrvatska zajednica, Hrvatska težačka stranka), članovi Jugoslovenskog kluba (SLS, Hrvatska pučka stranka, Bunjevačkošokačka stranka). ${ }^{22}$ Nakon proglašenja Obznane 29. decembra 1920. uskraćeno je djelovanje i Komunističke partije Jugoslavije. Ona je stavljena van zakona. Na napuštanje Ustavotvorne skupštine od strane komunističkih poslanika početkom juna 1921. niko od članova tog predstavničkog tijela nije se ni osvrnuo. ${ }^{23}$ Rad Konstituante praćen je brojnim sukobima, kršenjem odredaba poslovnika i samovoljom regenta Aleksandra. Zbog toga je broj poslanika sa prvobitno odabranih 419 spao na $258 .^{24}$ To je predstavljalo opasnost za cjelokupni ustavnopravni proces budući da je bilo izvjesno da se neće moći osigurati dovoljna većina za izglasavanje ustava. Tako je vlada u potrazi za podrškom krenula u pregovore sa većim brojem stranaka: Jugoslovenskom muslimanskom organizacijom, Zemljoradničkom strankom, Slovenskom kmetijskom strankom i Džemijetom. Sredinom marta 1921. Jugoslovenska muslimanska organizacija je postavila dvije grupe zahtjeva koje je vlada trebala ispuniti kako bi se obezbijedili glasovi za izglasavanje ustava. Jedni su trebali biti uneseni u ustav, a druge je vlada trebala kasnije direktno realizovati.

Poslije dugotrajnih i iscrpnih pregovora 12. marta 1921. postignut je konačni sporazum. Vlada Nikole Pašića je obećala da će u novi ustav inkorporirati rješenja iz ustavnog nacrta Jugoslovenskog muslimanskog kluba koji su se odnosili na zaštitu i ravnopravnost vjera, vjersko-prosvjetnu autonomiju, radu šerijatskih sudova, izbornom sistemu koji će štiti manjine, a ugovorne strane su se složile da u kraljevsku vladu uđu dva ministra iz reda JMO, a istoj stranci su data četiri mjesta u Zemaljskoj vladi Bosni i Hercegovini. Posebno je insistirano da se prilikom uspostave novog upravnog i ustavnog sistema poštuje teritorijalni integritet Bosne i Hercegovine. Sa prihvatanjem uslova od strane vlade JMO se obavezala da će uzeti "u pretres vladino gledište o unutrašnjem državnom uređenju". ${ }^{25}$ Obrazlažući svoj

Hercegovine, Sarajevo 2019, 57-93.

22 Konačna verzija ustava bila je bazirana na prijedlogu Nikole Pašića uz određene izmjene (prvobitno je, primjera radi, bio predviđen dvodomni sistem, od koga se odustalo). O svima drugim nacrtima nije se skoro ni vodilo računa. Jedino su poslanici, članovi Ustavnoga odbora, pokušavali, prilikom diskusija, da neke odredbe Ustava izmijene u smislu ustavnih nacrta svojih klubova, ali bez nekog većeg uspjeha - vidi: M. Đorđević, Istorijat izbora u Kraljevini SHS i Kraljevini Jugoslaviji, 299-300.

23 Ferdo Čulinović, Jugoslavija između dva rata, sv. 1, Izdavački zavod Jugoslavenske akademije znanosti i umjetnosti, Zagreb 1961, 346. (dalje: F. Čulinović, Jugoslavija između dva rata, I); Ivana Zebec-Žilj, Pregled općeg političkog stanja u Kraljevini Srba, Hrvata, Slovenaca kasnije Kraljevini Jugoslaviji, Studia lexicographica, br. 22, Zagreb 2018, 27-45. (dalje: I. Zebec-Žilj, Pregled općeg političkog stanja u Kraljevini Srba, Hrvata, Slovenaca kasnije Kraljevini Jugoslaviji).

24 Pošto su Ustavotvornu skupštinu napustili poslanici tzv. 'Narodnog kluba (još tokom debate o Ustavu u načelu), i komunistički poslanici (11. juna), zatim i poslanici Jugoslavenskog kluba, a pošto su od svakog rada u toj Skupštini već od početka apstinirali i poslanici iz redova Radićeve Hrvatske seljačke pučke stranke (50 poslanika) sa dva poslanika iz Hrvatske stranke prava, to je radikalskodemokratska grupa u ovom predstavničkom - tijelu smatrala, da je sada sigurna za izglasavanje Ustava, kakav je predložio Ustavni odbor - prema: F. Čulinović, Jugoslavija između dva rata, I, 348.

25 Branko Petranović-Momčilo Zečević, Jugoslovenski federalizam: ideje i stvarnost - tematska zbirka dokumenata, Tom I, Prosveta, Beograd 1987, 190-191. 
ulazak u vladu i davanje podrške centralistički orijentisanom ustavu predsjednik JMO Mehmed Spaho je na sjednici skupštine u junu 1921. izjavio da je za glasove njegove stranke presudno bilo garantiranje kompaktnosti muslimana u Bosni i Hercegovini. On je dalje isticao da je to urađeno zato što vladi, koja je na sebe uzela dužnost da zemlji donese Ustav, nije bilo moguće doći do većine koja je poslovnikom bila potrebna za donošenje Ustava. ${ }^{26} \mathrm{Uz}$ to Vlada se obavezala i da će pružiti materijalnu pomoć islamskim vjerskim i vakufskim ustanovama, te da će riješiti pitanje naknade vlasnicima za oduzete i otete kmetovske i beglučke zemlje. ${ }^{27}$

Izglasavanje Ustava obavljeno je 28. juna 1921. na srpski praznik -Vidovdan, zbog čega je ovaj dokument nazvan Vidovdanski ustav. Izglasan je prevashodno zahvaljujući podršci "muslimanskih poslanika" (JMO iz Bosne i Hercegovine i Džemijeta - "Islam Muhafazai Hukuk Cemiyet" - Društva za zaštitu muslimanskih prava iz „Južne Srbije”). U pridobijanju njihovih glasova korišćena su razna sredstva, od pritisaka do podmićivanja. ${ }^{28}$ Postupak glasanja je tekao u napetoj atmosferi. Za ustav je glasalo ukupno 223 poslanika: demokrata (92), radikala (91), predstavnika Jugoslovenske muslimanske organizacije (23), slovenskih kmetijaca (10) i Džemijeta (8). Protiv ustava je glasovalo 35 zastupnika (socijaldemokrati, republikanci, zemljoradnici i dr. Ante Trumbić), dok ih je 161 apstinirao, među kojima su bili zastupnici Hrvatske republikanske seljačke stranke, te 58 zastupnika KPJ. ${ }^{29}$ Centralističko uređenje bilo je povod izbijanju velikog

26 O. Sušić, Položaj Bosne i Hercegovine u Vidovdanskom ustavu, 227-237; Amra Mahmutagić, Specifičnosti bosanskohercegovačke državnosti u Jugoslaviji između dva svjetska rata, Revija za ekonomiju i pravo, br. 1, Pravni fakultet, Univerzitet Džemal Bijedić u Mostaru, Mostar 2015, 8182. (dalje: A. Mahmutagić, Specifičnosti bosanskohercegovačke državnosti u Jugoslaviji između dva svjetska rata).

27 Dr. Atif Purivatra ustvrđuje da je "u okolnostima u kojima je djelovala JMO bilo "vrlo teško postići išta više nego što je postignuto. Čak i ono što je postignuto, mislim da je gotovo maksimalno što se moglo postići. Bilo je to vrijeme oduzimanja zemlje i aktueliziranja ideja o likvidiranju Muslimana ili njihovom protjerivanju. Prevladavalo je shvatanje da treba obezvrijediti Muslimane u svakom pogledu: kulturnom, političkom i pogotovo gospodarskom, jer su, kada je ekonomija u pitanju, Muslimani dominirali u Bosni i Hercegovini”. U tadašnjim "međunarodnim okolnostima srbijanskoj vladi je bilo izuzetno stalo da Kraljevina SHS kao nova evropska država dobije međunarodni ugled i legitimitet pa je nastojala da se Vidovdanski ustav izglasa i glasovima nesrpskih poslanika. U takvoj situaciji Spaho je iskoristio podršku JMO novom Ustavu da se potpiše ugovor o obaveznoj isplati obveznica za oduzetu zemlju u visini od 225 miliona dinara. Postići nešto više bilo je vrlo teško... Naravno, JMO je izigrana jer ugovor koji je potpisan nije ispoštovan i odštete nisu isplaćene, odnosno jedan vrlo mali dio je isplaćen u gotovom, a ostalo je dato u papirima koji su sve do 1972. godine trebali da se isplaćuju a nisu" - prema: "Dani”, br. 103, Sarajevo, 21. maj 1999.

28 Opšir. vidi: Branko Petranović-Momčilo Zečević, Agonija dve Jugoslavije, Beograd 1991, 59; M. Đorđević, Istorijat izbora u Kraljevini SHS i Kraljevini Jugoslaviji, 300; Muhidin Pelesić, Drijemanje na ramenu vremena ili žudnja za vlašću predvodnika iznad nada i strahova sunarodnjaka (Bošnjački političari u prevratničkom vremenu sloma Imperije i rođenja Kraljevine), Historijska traganja, br. 3, Institut za historiju, Sarajevo 2009, 70; Uroš Šuvaković, Korupcija i političke stranke u Kraljevini, Srba, Hrvata i Slovenaca, NPB, Žurnal za kriminalistiku i pravo, br. 1, Kriminalističko-policijska akademija, Beograd 2011, 62-66.

29 A. Mahmutagić, Specifičnosti bosanskohercegovačke državnosti u Jugoslaviji između dva svjetska rata, 81 . 
nezadovoljstva stranaka sa autonomističkom i decentralističkom orijentacijom. Tako je 21. maja 1921. prije izglasavanja ustava javnosti upućen proglas svih hrvatskih stranaka u kojem je istaknuto da hrvatski predstavnici ne prihvataju ustav donešen bez njihove prethodne konsultacije. Upućivani su brojni apeli međunarodnoj zajednici sa posebnim naglaskom na štetnost vidovdanskog uređenja po položaj Hrvatske ali bez značajnijeg uspjeha. ${ }^{30}$ Vidovdanski ustav je postao "jabuka razdora" jer je usvojen prostom a ne dvotrećinskom većinom, kako su se u julu 1917. politički predstavnici Srba i Hrvata dogovorili na Krfu. Način promjene ovog ustava sadržavao je elemente referenduma, što mu je davalo obilježje naročito čvrstog ustava. ${ }^{31}$

Osiguravajući svojim glasovima potrebnu većinu vladi, JMO je primila na sebe veliku političku odgovornost, pošto se bez njene podrške ovaj ustav ne bi mogao donijeti. Međutim, nije "cijela istina" u tome da je glasovima JMO omogućeno donošenje Vidovdanskog ustava, već i u činjenici da su i druge političke stranke, rukovođene svojim interesima koje su u Konstituanti zastupale, donijele ovaj ustav gledajući u njemu garanciju da će se upravo ti interesi u društvu i državi uvažavati. ${ }^{32}$ Osuđivana zbog toga od strane opozicije, JMO nije bila cijenjena ni u vladinim krugovima, u kojima su se njeni poslanici tretirali kao "plaćenici", kupljeni da glasaju za Ustav. Izlaz iz ovog neugodnog, kompromitirajućeg položaja, vođstvo JMO vidjelo je u povratku svome stranačkom programu, a to je značilo suprotstavljanje političkom sistemu čijoj je izgradnji inače dat znatan doprinos..$^{33}$ Mehmed Spaho 1923. piše da "sve, što nije srpsko i pravoslavno, sve što nije voljno da pomaže i odobrava nezasitne prohtjeve centralista, proglašuje većina beogradske štampe protudržavnim elementima, kojima treba oduzeti sva građanska prava". ${ }^{34}$

30 I. Zebec-Žilj, Pregled općeg političkog stanja u Kraljevini Srba, Hrvata, Slovenaca kasnije Kraljevini Jugoslaviji, 33.

31 Ustavi se dijele na čvrste i meke, prema pravnim režimima za njihove promjene. Čvrsti ustavi su oni koji se mijenjaju posebnim postupkom, težim od običnog zakonodavnog - prema: Zoran Jerotijević-Sveto Purić, Ustavnopravni razvoj Kraljevine SHS i Kraljevine Jugoslavije 1918-1941. sa posebnim osvrtom na formiranje Banovine Hrvatske, Ekonomika, Društvo ekonomista "Ekonomika", br. 2, Niš 2013, 111.

32 Enver Redžić, Nekoliko napomena o "Pregledu istorije SKJ", Prilozi, br. 1, Sarajevo 1965, 355. Atif Purivatra je ukazao da nije bilo nikakve sumnje, nakon raznovrsnih mahinacija, od sporazumijevanje do prijetnji i nasilja, da će Ustav biti donesen po želji vladine koalicije: "Radikali i demokrati, svjesni da nemaju potrebnu većinu, tražili su i našli saveznike u 'malim' političkim partijama, čija politika, posebno u tadašnjoj konstelaciji političkih odnosa, nije mogla biti drukčija nego prakticistička, sporazumaška, lavirajuća. Pitanje je samo bilo, kojoj od njih učiniti manje ustupke i koja od njih u konkretnoj situaciji bolje odgovara", navodeći dalje: "Opravdano se može pretpostaviti da bi vladina koalicija postigla sporazum sa Zemljoradnicima, da se nije nagodila sa Jugoslavenskom muslimanskom organizacijom" - nav. prema: Atif Purivatra, Tri pitanja iz političkog života Bosne i Hercegovine, Prilozi, br. 1, Institut za istoriju radničkog pokreta, Sarajevo 1965, 409-410.

33 Upor. Branislav Gligorijević, Parlament i političke stranke u Jugoslaviji (1919-1929), Institut za savremenu istoriju, Beograd 1979, 111; Nusret Šehić, Bosna i Hercegovina 1918-1925, Sarajevo 1991, 204-206.

34 Čitavo javno mnjenje u Beogradu je po njemu, jednostrano, "slabo obaviješteno o prilikama u pojedinim krajevima države, a što je još gore, ono je vrlo rđavo raspoloženo prema nesrpskom i 
Spahina podrška Vidovdanskom ustavu dovela je do prvih stranačkih rascjepa unutar JMO - između pristaša nastavka saradnje na vidovdanskoj ustavnoj platformi i zagovornika obnove autonomnog statusa Bosne i Hercegovine uz uspostavu bližih odnosa sa hrvatskom autonomističkom opozicijom okupljene oko Hrvatske republikanske seljačke stranke Stjepana Radića. ${ }^{35}$

Ustav nove države donijet je nakon tri godine njenog postojanja. Iako, po definiciji, složena država nastaje ustavom, u ovom slučaju postojalo je netipčno rješenje da je prvozajednička vlast nove države počela da funkcioniše, pa je tek nakon nekoliko godina usvojen ustav kao osnovni akt države..$^{36}$ Vidovdanski ustav je, po svojoj pravnoj prirodi, spadao u kategoriju krutih ustava, jer se njegove izmjene nisu mogle vršiti na način predviđen za donošenje ili izmjenu zakona, nego jedino po posebnom postupku i uz poseban kvorum poslanika u Narodnoj skupštini. ${ }^{37}$ Ustavom je stvorena centralizirana država koja je počivala na sljedećim načelima: nacionalnom unitarizmu, državnom centralizmu, monarhijskom obliku vladavine, ograničenoj formi parlamentarizma i privatno-vlasničkom ekonomskom poretku. Na bazi pretodno spomenutog unitarizma Srbi, Hrvati i Slovenci su smatrani jedinstvenim troplemenim narodom, dok ostali narodi i narodnosti uopće nisu spominjani. Polazeći od ovakvog stava, Ustavom je ozakonjeno centralističko državno uređenje, po principu jedan narod jedna država, negirajući na taj način svaku regionalnu i nacionalnu posebnost. ${ }^{38}$ Do 1929 . zajednička država bila je na osnovi konstitutivnosti tri naroda (Srbi, Hrvati i Slovenci). Početna slova iz naziva naroda činila su skraćeni naziv same države - SHS. Trostrukost nacionalne konstitutivnosti je 1929. nasilno zamijenjena jugoslovenstvom. ${ }^{39}$

Kraljevska vlada je u članu 135. predvidjela da će teritorija Bosne i Hercegovine ostati unutar postojećih granica na način da važeći okruzi nastavljaju egzistirati kao oblasti sve do donošenja posebnog zakona o podjeli zemlje na oblasti, općine i srezove. Spomenuti član je u štampi dobio naziv "turski paragraf", pošto su, navodi Atif Purivatra, muslimani, odnosno "Turci", kako su ih nerijetko nazivali,

nepravoslavnom stanovništvu naše države"; opšir. Mehmed Spaho, Zašto smo protiv centralizma? Kalendar JMO za 1923, preštampano u: Godišnjak, BZK "Preporod”, god. I, Sarajevo 2001, 180-182. 35 Zlatko Hasanbegović, Jugloslavenska muslimanska organizacija 1929 - 1941 (U ratu i revoluciji 1941 - 1945), Bošnjačka nacionalna zajednica za Grad Zagreb i Zagrebačku županiju, Zagreb 2012, 24-25.

36 Pošto je u ovom periodu postojala faktička državna vlast koja je funkcionisala na osnovu pojedinih zakona Kraljevine Srbije, vrijeme od 1. decembra 1918. do donošenja Vidovdanskog ustava, naziva se periodom državno-pravnog provizorijuma. Ono obuhvata vremensko razdoblje kada je državna vlast u realnosti funkcionisala, ali je u pitanju "faktička vlast, vlast koja se nije vršila na osnovu pravnih akata" - prema: Sava Aksić, Period državno-pravnog provizorijuma prve zajedničke države Južnih Slovena (1918-1921), Zbornik radova Filozofskog fakulteta u Prištini, br. 47-2, Kosovska Mitrovica 2017, 226.

37 Branko Petranović, Istorija Jugoslavije 1918-1978, Nolit, Beograd 1981, 54.

38 Radomir Nešković, Nedovršena država: politički sistem Bosne i Hercegovine, Fondacija Friedrich-Ebert Stiftung, Sarajevo 2013, 84.

39 Branislav Gligorijević, Parlamentarni sistem u Kraljevini Srba, Hrvata i Slovenaca 1919-1929, u: Zbornik radova: Politički život Jugoslavije 1914-1945, Beograd 1973, 369-370. 
glasali za njega. ${ }^{40}$ Bilo je predviđeno da se pojedine opštine ili srezovi mogu "iz svojih oblasti izlučiti i pripojiti drugoj oblasti u sadašnjim granicama i Bosne i Hercegovine ili izvan njih, ako na to pristanu njihova samoupravna predstavništva odlukom od 3/5 glasova i tu odluku odobri Narodna skupština". Iz ovog, 135. člana Ustava vidi se jasno, upućuje Seka Brkljača, da je politički propagandno hvaljeni tzv. "turski paragraf" ostavljao mogućnost da se Bosna i Hercegovina, koja je jedinstvena teritorijalno samo u vanjskim granicama oblasti, može i drugačije organizovati, tj. njena teritorija podijeliti. ${ }^{41}$ Ovakvo ustavno rješenje je naišlo na nezadovoljstvo muslimanskih predstavnika. Mehmed Spaho je javno istupio pred poslanicima Ustavotvorne skupštine rekavši da se takvim ustavnim rješenjem ne garantira cjelovitost i kompaktnost koja je Bosni i Hercegovini prethodno obećana. Ipak su postojećih šest oblasti: Sarajevska, Bihaćka, Mostarska, Travnička, Tuzlanska, Vrbaska (Banjalučka) zadržane čime je u određenoj mjeri ispoštovan sporazum iz marta 1921. godine. ${ }^{42}$

Vidovdanski ustav je u svom članu 134. predviđao privremeno postojanje pokrajinskih uprava kojima su upravljali posebni namjesnici imenovani od ministarstva unutrašnjih poslova. U Bosni i Hercegovini je, u tom smislu, postojeća Zemaljska vlada obavljala sve poslove do 21. jula 1921. kada je uspostavljena posebna Pokrajinska uprava za Bosnu i Hercegovinu. Riječ je o čisto formalnom postupku budući da je posljednji predsjednik vlade, Nikola Đurđević, nakon podnošenja ostavke odmah izabran za namjesnika. ${ }^{43} \mathrm{U}$ stavu 3. istog člana je propisano da se prilikom donošenja prijedloga općeg karaktera ili u vezi sa službenim osobljem obezbijedi mišljenje pokrajinskog namjesnika prije konsultiranja ministarstva unutrašnjih poslova čime su namjesnici imali uvid u sve poslove organa uprave u zemlji.

40 Članom 135. Vidovdanskog ustava određeno je da Bosna i Hercegovina "ostaje u svojim sadašnjim granicama", te da postojeći okruzi u njoj "važe kao oblasti”. Sve ostale zemlje i historijske pokrajine koje su ušle u sastav nove države su izdijeljene u oblasti, bez obzira na njihove dotadašnje granice - prema: Mustafa Imamović, Knjiga pamćenja, University press, Sarajevo 2013, 562-563.

41 Seka Brkljača, Paradoksi provedbe Vidovdanskog ustava iz 1921. godine u Bosni i Hercegovini, Historijska traganja, br. 7, Institutt za istoriju, Sarajevo 2011, 44-146. (dalje: S. Brkljača, Paradoksi provedbe Vidovdanskog ustava iz 1921. godine u Bosni i Hercegovini). Vidovdanskim ustavom, kao i kasnijim Zakonom o podjeli države na 33 oblasti, od kojih se šest odnosilo na Bosnu i Hercegovinu u historijskim granicama, bila proklamirana teritorijalna cjelovitost Bosne i Hercegovine, ali istovremeno i ostavljena mogućnost za razbijanje te cjelovitosti. To će se i desiti 1929. ali ne pozivanjem na tu mogućnost datu u ustavu, nego u doba diktature, kad je ustav već bio suspendiran prema: H. Kamberović, U stalnom procepu, 66-67.

42 Ljubomir Zovko, Pitanje položaja Bosne i Hercegovine i njene administrativno-teritorijalne podjele u Kraljevini SHS (1921-1929), u: Edin Mutapčić (ur), Zbornik radova naučnog skupa: Ustavno pravni razvoj Bosne i Hercegovine (1910-2010), Pravni fakultet Univerziteta u Tuzli, Tuzla 2011, 149-161. (dalje: Lj. Zovko, Pitanje položaja Bosne i Hercegovine i njene administrativnoteritorijalne podjele u Kraljevini SHS).

43 Upor. Nusret Šehić, Ustavne koncepcije i donošenje Vidovdanskog ustava 28. juna 1921. godine, Sveske, br. 28-29, Institut za proučavanje nacionalnih odnosa, Sarajevo 1990, 381-382; M. Imamović, Historija države i prava Bosne i Hercegovine, 306. 
U organizacionom sastavu Pokrajinske uprave za Bosnu i Hercegovinu ostalo je samo pet odjeljenja, i to za unutarnje poslove, (resor Ministarstva unutarnjih poslova), poljoprivredu i vode sa Generalnom inspekcijom rada (resor Ministarstva poljoprivrede i voda), pravosuđe (resor Ministarstva pravde), prosvjetu i vjere (resor Ministarstva prosvjete i Ministarstva vjera) i socijalnu politiku (resor Ministarstva socijalne politike). U ovako modificiranom obliku uprava je nastavila sa radom i nakon donošenja Zakona o oblasnoj i sreskoj samoupravi u aprilu 1922. kojom je Kraljevina SHS podijeljena na 33 oblasti u koje su uključene i ranije oblasti u Bosni i Hercegovini. Time je, u duhu Ustava, otvoren put državnom centralizmu. ${ }^{44}$ Iako se Bosna i Hercegovina nalazila u središtu države ona je produžila svoju periferijalnost "provincije u pozadini". ${ }^{45} \mathrm{U}$ poratnim godinama u njoj je od poljoprivrede živjelo $86,37 \%$ stanovništva, a svega $13,63 \%$ bavilo se nepoljoprivrednim zanimanjima. ${ }^{46}$

Centralna vlast u Beogradu je od sredine iste godine insistirala na ukidanju pokrajinskih uprava koje su smatrane kao svojevrsni oblici državnosti i samostalnosti što nije bilo u skladu sa vladajućim političkim opredjeljnjima. U augustu 1922. na poziciju namjesnika u Bosni i Hercegovini imenovan je bivši načelnik mostarskog okruga Ljubomir Vulović sa zadatkom da ukine rad ovog organa. Pokrajinski poslovi su trebali biti prebačeni na velike župe, a drugim dijelom na nadležna ministarstva. Radilo se o izuzetno dugom i komplikovanom poslu koji je trajao od decembra 1923. do 25. februara 1924. kada je Vulović izvijestio Ministarstvo unutrašnjih poslova u Beogradu o okončanju postupka ukidanja pokrajinskih organa. Tom prilikom je istaknuto da "uslijed toga nema više odjeljenja niti odsjeka Pokrajinske uprave za Bosnu i Hercegovinu i time je ista potpuno prestala postojati. Ovim povodom udovoljavam konačno i naređenju Gospodina Ministra unutrašnjih dela". ${ }^{47}$ Time je, nakon skoro pet godina postojanja, ukinuta Pokrajinska uprava i uvedena nova administrativna podjela u skladu sa Zakonom o podjeli zemlje na oblasti iz aprila 1922. godine. Ovakvo stanje će potrajati sve do zavođenja šestojanuarske diktature 1929. godine. Centralizacija države 1921. pretpostavljala je globalnu unifikaciju regula sfera društvenog života, zakona, carina, poreza, taksi. Paradoksalno je što se u tim sferama, pored zadržavanja naslijeđene neujednačenosti po historijskim pokrajinama, kojih od Ustava 1921. više nema, da se taj nesklad "izjednačavanjem" dalje produbljivao.

44 Branko Dubravica, Primorska banovina u politici upravne podjele Bosne i Hercegovine, Politička misao, br. 4, Zagreb 2011, 159; opšir. Ivica Lučić, Bosna i Hercegovina u Kraljevstvu Srba, Hrvata i Slovenaca, s posebnim osvrtom na stanje u Hercegovini (1918-1921), u: Godina 1918: prethodnice, zbivanja i posljedice, Hrvatski institut za povijest, Zagreb 2010, 207-245.

45 Kasim Suljević, Nacionalnost Muslimana. Između teorije i prakse, 91.

46 Bosna i Hercegovina su »srpske zemlje«, ali "krupni kapitalisti Srbije nisu to gledište potvrđivali ulaganjem svoga kapitala" u privredni razvoj Bosne i Hercegovine - prema: Enver Redžić, Jugoslavenski radnički pokret i nacionalno pitanje u Bosni i Hercegovini (1918-1941) Sarajevo 1983, 94.

47 Lj. Zovko, Pitanje položaja Bosne i Hercegovine i njene administrativno-teritorijalne podjele u Kraljevini SHS, 152. 
Selektivne promjene "nivelisanja“ išle su na štetu u svojoj konačnici i Bosne i Hercegovine, koja, sve do jedinstvenog Zakona o porezima, izvršnog od 1. januara 1929, Zakona o taksama iz 1930, Zakona o lokalnim zajednicama iz 1933/1934, u sferi tih propisa ostaje zasebno područje, iako je Vidovdanski ustav nije prepoznavao kao takvu, a naročito od 1929. i podjele države na banovine. ${ }^{48}$ Nakon njihovog stvaranja Bosna i Hercegovine je podijeljena i izgubila je svoju teritorijalnu cjelovitost.

\section{Zaključak}

Nakon završetka Prvog svjetskog rata na evropskoj političkoj sceni pojavljuju se nove države nastale na ruševinama nekadašnjih velikih carevina. Jedna od njih je Kraljevina Srba, Hrvata, Slovenaca nastala u decembru 1918. ujedinjenjem Kraljevine Srbije i južnoslavenskih zemalja koje su bile u sastavu nekadašnje Austrougarske monarhije. Nova država je okupila različite narode, kulture i vjere, zajednice sa različitim vizijama budućnosti, što je dovelo i do kriza i pojave različitih pogleda o uređenju buduće južnoslavenske države. Te su se suprostavljenosti došle do svog punog izražaja u radu Ustavotvorne skupštine gdje su u većoj ili manjoj mjeri tinjali sukobi između pristlica monarhističke, centralizovane države i onih koji su se zalagali za decentralizovanu zemlju. Suočena sa sve većim brojem poslanika koji su zbog nezadovoljstva u odnosima sa centralistički orijentisanom vladom i dominatnim srpskim strujama napuštali rad Konstituante, a što je moglo dovesti do kraha cijelog procesa izglasavanja ustava, vlada započinje pregovarati sa ostalim strankama u cilju osiguranja prijeko potrebne većine. Dogovor je postigla, između ostalog, i sa Jugoslovenskom muslimanskom organizacijom sa Mehmedom Spahom na čelu. Tom prilikom su muslimanski političari obećali dati svoju podršku novom ustavu u zamjenu za rješavanje niza pitanja koja su mučila tadašnje muslimansko stanovništvo u Bosni i Hercegovini: od vakufsko-mearifske autonomije, agrarne reforme pa sve do očuvanja teritorijalne cjelovitosti Bosne i Hercegovine. Vlast je prihvatila ove zahtjeve, posebice onaj koji se odnosi na cjelovitost Bosne i Hercegovine, uključivši ga u tekst Ustava, tačnije član 135. kojim je predviđeno da tadašnjih šest okruga u Bosni i Hercegovini ostaju da egzistiraju kao oblasti. Ovaj paragraf, ubrzo u štampi, prozvan "Turski" i "Spahin paragraf", imao je svoje pozitivne i negativne refleksije. Pozitivne su manifestovane u očuvanju teritorijalnog integriteta Bosne i Hercegovine, a negativne su se odrazile po sam Spahin ugled i stanje u njegovoj stranci. Često optuživani za prodaju svojih glasova za ustav, muslimanski predstavnici su se podijelili na autonomističku struju i one koji su dalje sarađivali sa vlašću. "Turski paragraf" je prestao da važi 1924. godine, kada se, shodno drugim odredbama Vidovdanskog ustava, završava organizovanje oblasti u državi i zavodi centralizacija uprave.

48 S. Brkljača, Paradoksi provedbe Vidovdanskog ustava iz 1921. godine u Bosni i Hercegovini, 144. 


\section{Summary}

After the end of the First World War, new states appeared on the European political scene, created on the ruins of the former great empires. One of them is the Kingdom of Serbs, Croats, Slovenes, created in December 1918 by the unification of the Kingdom of Serbia and the South Slavic countries that were part of the former Austro-Hungarian monarchy. The new state brought together different peoples, cultures and religions, communities with different visions of the future, which led to crises and the emergence of different views on the organization of the future South Slavic state. These oppositions came to full expression in the work of the Constituent Assembly, where conflicts between the supporters of the monarchist, centralized state and those who advocated a decentralized country were more or less simmering. Faced with a growing number of lawmakers who left the Constituent Assembly due to dissatisfaction with relations with the centralist government and dominant Serb currents, which could lead to the collapse of the entire constitutional process, the government began negotiations with other parties to secure the muchneeded majority. She reached an agreement, among other things, with the Yugoslav Muslim Organization, headed by Mehmed Spaho. On that occasion, Muslim politicians promised to give their support to the new constitution in exchange for resolving a number of issues that plagued the then Muslim population in Bosnia and Herzegovina: from waqf-mearif autonomy, agrarian reform to preserving the territorial integrity of Bosnia and Herzegovina. The authorities accepted these demands, especially the one concerning the integrity of Bosnia and Herzegovina, including it in the text of the Constitution, namely Article 135, which stipulates that the then six districts in Bosnia and Herzegovina remain as areas. This paragraph, soon in the press, called "Turkish" and "Spaho's paragraph", had its positive and negative reflections. The positive ones were manifested in the preservation of the territorial integrity of Bosnia and Herzegovina, and the negative ones were reflected in Spaho's reputation and the situation in his party. Often accused of selling their votes for the constitution, Muslim representatives split into an autonomist faction and those who further cooperated with the government. The "Turkish paragraph" ceased to be valid in 1924, when, in accordance with other provisions of the Vidovdan Constitution, the organization of areas in the state was completed and the centralization of administration began. 